\title{
Meconium peritonitis: an interesting entity
}

\author{
Deepak Sharma, Srinivas Murki, Tejo Pratap
}

Department of Neonatology, Fernandez Hospital, Hyderabad, Andhra Pradesh, India

\section{Correspondence to} Dr Deepak Sharma; dr.deepak. rohtak@gmail.com

Accepted 3 April 2014

\section{CrossMark}

To cite: Sharma D, Murki S,
Pratap T. BMJ Case Rep
Published online: [please
include Day Month Year]
doi:10.1136/bcr-2014-
203536

To cite: Sharma D, Murki S, Pratap T. BMJ Case Rep Published online: [please doi:10.1136/bcr-2014203536

\section{DESCRIPTION}

A pair of late preterm twin female babies with a birth weight of $2.8 \mathrm{~kg}$ and $2.6 \mathrm{~kg}$ were born to G2P0A1L0 mother with a normal Apgar score. Antenatally fetus A was diagnosed to have echogenic small bowel (grade 3) with few specks of peritoneal calcification. Antenatal scans of fetus B were normal. After birth, X-ray and ultrasound of both the babies were done. The X-ray of baby A showed peritoneal calcification in the right hypochondrium region with absence of air under the diaphragm (figures 1 and 2), whereas the X-ray of the second twin was normal. Ultrasonography (USG) carried out on both babies was normal. There was no obvious malformation in both the babies at birth. Both the twins passed meconium within $24 \mathrm{~h}$ of birth. Both the babies were evaluated with newborn screening carried out for cystic fibrosis, which was normal in both babies. Now both babies are in our follow-up.

\section{DISCUSSION}

Meconium peritonitis is a result of sterile chemical peritonitis which results due to intrauterine bowel perforation and exudation of meconium into the peritoneal cavity. Meconium undergoes dystrophic calcification intrauterine, which results in the classic eggshell calcifications seen on X-ray. ${ }^{1}$ The estimated prevalence is around 1 in $35000 .^{2}$

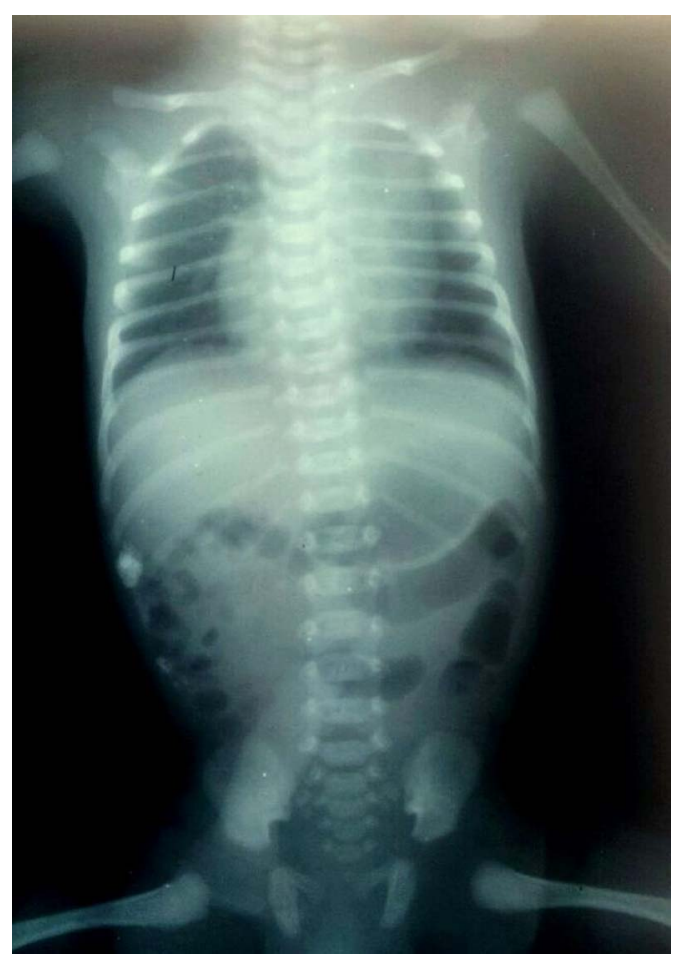

Figure 1 Peritoneal calcification in the right hypochondrium region with absence of air under the diaphragm.

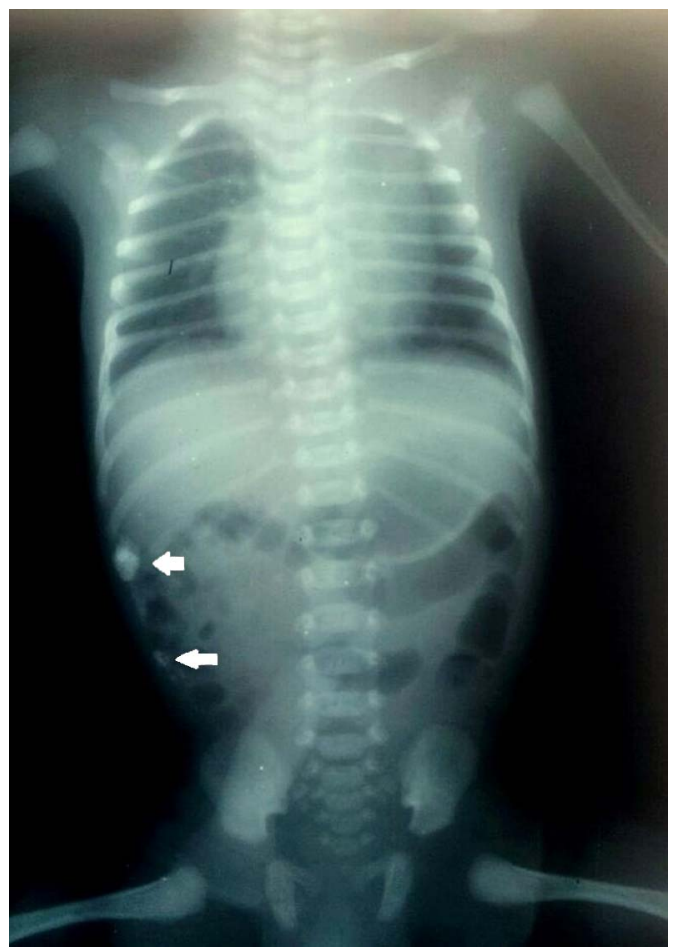

Figure 2 Peritoneal calcification in the right hypochondrium region with absence of air under the diaphragm (calcification is shown by arrow head).

Meconium peritonitis is classified into three groups as per the antenatal USG findings:

- Type I: large meconium ascites

- Type II: large pseudocyst

- Type III: Intra-abdominal calcifications, small meconium ascites and/or a shrinking pseudocyst. $^{3} 4$

Our patient had type III meconium peritonitis.

The other differential diagnosis of meconium peritonitis which also present with intra-abdominal calcification are

- Meconium pseudocyst

- Intraluminal meconium calcification

- Liver calcification in the neonate following congenital infections

- Adrenal calcification

\section{Learning points}

- Meconium peritonitis can present in various ways in a newborn and the index of suspicion must be high.

- All these babies must be screened for cystic fibrosis as it is common in these babies.

- Meconium peritonitis must be kept as the differential diagnosis of intra-abdominal calcification in neonates. 
- Mesenteric nodes

- Hepatic granulomas

Neonatal outcomes have improved over time as a result of better diagnosis antenatally and with modern advances in paediatric surgery and perinatology. ${ }^{5}$ Surgery remains the definitive treatment with procedures including multiple drainage procedures, stoma creation and final ostomy closure. ${ }^{6}$

Contributors DS wrote the primary draft. TP undertook critical analysis of the manuscript. SM undertook critical analysis and was involved in final correction of the manuscript.

Competing interests None.

Patient consent Obtained.

Provenance and peer review Not commissioned; externally peer reviewed.

\section{REFERENCES}

1 Foster MA, Nyberg DA, Mahony BS, et al. Meconium peritonitis: prenatal sonographic findings and their clinical significance. Radiology 1987; 165:661-5.

2 Berrocal T, Lamas M, Gutieérrez J, et al. Congenital anomalies of the small intestine, colon, and rectum. Radiographics 1999;19:1219-36.

3 Nam SH, Kim SC, Kim DY, et al. Experience with meconium peritonitis. J Pediatr Surg 2007;42:1822-5

4 Tseng JJ, Chou MM, Ho ES. Meconium peritonitis in utero: prenatal sonographic findings and clinical implications. J Chin Med Assoc 2003; 66:355-9.

5 Miyake $\mathrm{H}$, Urushihara N, Fukumoto K, et al. Primary anastomosis for meconium peritonitis: first choice of treatment. J Pediatr Surg 2011; 46:2327-31.

6 Valladares E, Rodríguez D, Vela A, et al. Meconium pseudocyst secondary to ileum volvulus perforation without peritoneal calcification: a case report. J Med Case Rep 2010;4:292.

Copyright 2014 BMJ Publishing Group. All rights reserved. For permission to reuse any of this content visit http://group.bmj.com/group/rights-licensing/permissions.

BMJ Case Report Fellows may re-use this article for personal use and teaching without any further permission.

Become a Fellow of BMJ Case Reports today and you can:

- Submit as many cases as you like

- Enjoy fast sympathetic peer review and rapid publication of accepted articles

- Access all the published articles

- Re-use any of the published material for personal use and teaching without further permission

For information on Institutional Fellowships contact consortiasales@bmjgroup.com

Visit casereports.bmj.com for more articles like this and to become a Fellow 